\title{
Using video microscopy to improve quantitative estimates of protozoal motility and cell volume
}

\author{
B. A. Wenner, ${ }^{*} \dagger^{1}$ B. K. Wagner, ${ }^{*}$ and J. L. Firkins ${ }^{*} \dagger^{2}$ \\ *Department of Animal Sciences, The Ohio State University, 2029 Fyffe Ct., Columbus 43210 \\ †Interdisciplinary PhD Program in Nutrition, The Ohio State University, Columbus 43210
}

\begin{abstract}
The objective of this study was to apply digital imaging to improve quantification of rumen protozoal biomass and distinguish treatment differences in cell motility and volume among ruminal protozoa. Observations of protozoa in rumen fluid treated with essential oils (CinnaGar, CIN; Provimi North America, Brookville, $\mathrm{OH}$ ) or an ionophore (monensin, $\mathrm{MON}$ ) indicated possible cell shrinkage. We hypothesized that MON would decrease protozoal motility and interact with CIN on cell volume. In addition, we hypothesized that analysis of still frames from video of swimming protozoa would improve volume prediction accuracy. Flocculated rumen fluid was incubated in batch culture dosed with $\mathrm{N}$-free feed only (control), MON, CIN, or a combination of MON+CIN. Samples were taken at 0, 3, or $6 \mathrm{~h}$ post-treatment and wet-mounted on a microscope fitted with a high-definition camera. At $3 \mathrm{~h}$ postinoculation, there was a treatment interaction for average speed such that CIN attenuated the effect of MON, with treatment means of $243,138,211$, and $183 \mu \mathrm{m} / \mathrm{s}$ for control, MON, CIN, and MON+CIN, respectively. At $6 \mathrm{~h}$ post-inoculation, MON decreased average speed by $79.2 \mu \mathrm{m} / \mathrm{s}$ compared with the main effect mean without MON. We measured both minimum and maximum diameters (depth and width, respectively) perpendicular to the longitudinal axis of swimming protozoa, yielding a 3 -dimensional estimate of protozoal volume. The ellipsoid formula $(4 / 3) \pi a b c$, where $a=1 / 2$ length, $b=1 / 2$ width, and $c=1 / 2$ depth, was compared with previously published volume estimations using genera-specific coefficients (genera-specific coefficient $\times$ length $\times$ width $^{2}$ ). Residuals (genera-specific coefficients - ellipsoid) were plotted against predicted (ellipsoid) and centered to the mean $\left(\mathrm{X}_{\mathrm{i}}-\overline{\mathrm{x}}\right)$ to evaluate both mean and slope biases. For Entodinium spp.,
\end{abstract}

\footnotetext{
Received July 17, 2017.

Accepted September 28, 2017.

${ }^{1}$ Current address: Perdue AgriBusiness, Salisbury, MD 21804.

${ }^{2}$ Corresponding author: firkins.1@osu.edu
}

$\mathrm{Y}=0.248( \pm 0.037)\left(\mathrm{X}_{\mathrm{i}}-7.98 \times 10^{4}\right)+1.97 \times 10^{4}$ $\left( \pm 1.48 \times 10^{3}\right) ; \mathrm{n}=100 ; \mathrm{r}^{2}$ [coefficient of determination (squared correlation coefficient) $]=0.31$, with significant slope and mean biases. For family Isotrichidae, $\mathrm{Y}$ $=-0.124( \pm 0.068)\left(\mathrm{X}_{\mathrm{i}}-2.54 \times 10^{6}\right)-1.21 \times 10^{4}$ $\left( \pm 4.86 \times 10^{4}\right) ; \mathrm{n}=32 ; \mathrm{r}^{2}=0.10$, where slope tended to be different from zero but with no mean bias. For Epidinium spp., $\mathrm{Y}=0.375( \pm 0.056)\left(\mathrm{X}_{\mathrm{i}}-2.45 \times 10^{5}\right)+$ $6.65 \times 10^{4}\left( \pm 0.28 \times 10^{4}\right) ; \mathrm{n}=64 ; \mathrm{r}^{2}=0.43$, with both mean and slope biases. The present regression analyses demonstrate that the genera-specific coefficient-based method more likely overestimates volume for Entodinium and Epidinium than for the teardrop-shaped Isotrichidae. Based on simulations derived from previous literature reporting treatments that depress protozoal populations or among-animal changes in protozoal population structures, our proposed ellipsoid method offers potential to advance the prediction of treatment effects on protozoal volume and to shift focus from the number of cells present to the diversity, function, and biomass of protozoa under various treatment conditions.

Key words: rumen protozoa, protozoal volume, protozoal motility, monensin

\section{INTRODUCTION}

Rumen protozoa contribute to wasteful intraruminal $\mathrm{N}$ recycling resulting from predation of bacteria (Firkins et al., 2007) and associate with symbiotic methanogens (Vogels et al., 1980; Krumholz et al., 1983). Because of their hydrogenosomes or mitosomes (Hackstein and Tielens, 2010), ruminal protozoa represent a readily available source of $\mathrm{H}_{2}$ or formate to ecto- or endosymbiotic methanogens. Defaunation (the removal of protozoa from the rumen) has been associated with decreased methanogenesis (Eugène et al., 2004; Newbold et al., 2015), presumably resulting from disruption of methanogen symbiosis. Yet, those studies often reported depressed NDF digestibility, whereas protozoa are credited with improved ruminal fiber digestibility resulting from rumen $\mathrm{pH}$ stabilization in diets with rapidly 
Table 1. Equations for protozoal volume estimation referenced in this article

\begin{tabular}{lll}
\hline Equation $^{1}$ & Family or genera & Reference \\
\hline $0.8099 \times \mathrm{W}^{3}$ & All & Harmeyer and Hill (1964) \\
$\pi \times(\mathrm{L} / 4)^{2} \times \mathrm{L}$ & All & Teather et al. (1984) \\
$\pi \times(\mathrm{W} / 2)^{2} \times \mathrm{L}$ & All & Dehority (2010), Belanche et al. (2012) \\
$0.45 \times \mathrm{W}^{2} \times \mathrm{L}$ & Entodinium & Clarke et al. (1982) \\
$0.48 \times \mathrm{W}^{2} \times \mathrm{L}$ & Isotrichidae & Clarke et al. (1982) \\
$0.61 \times \mathrm{W}^{2} \times \mathrm{L}$ & Epidinium & Clarke et al. (1982) \\
$4 / 3 \times \pi \times a \times b \times c$ & All & Ellipsoid (proposed herein) \\
\hline${ }^{1} \mathrm{~L}=$ cell length, $\mathrm{W}=$ cell width, $a=1 / 2$ cell length, $b=1 / 2$ cell width, and $c=1 / 2$ cell depth.
\end{tabular}

available starch and sugar (Jouany and Ushida, 1999), oxygen consumption (Firkins et al., 2007), and physical shredding of fiber particles (Dehority, 2010). Newbold et al. (2015) noted that predation and fiber degradation were more active for order Entodiniomorphida, but members of family Isotrichidae need to be recognized for different associated methanogens (Belanche et al., 2015) and physiology, especially glycogenesis (Denton et al., 2015) and motility (Diaz et al., 2014a).

Not all protozoal cells contribute equally to their hydrolytic activity in the rumen, leading researchers to group protozoal counts by relative size (Eadie et al., 1970; Whitelaw et al., 1984; Williams and Coleman, 1992). Whitelaw et al. (1984) chose not to count protozoa because cell size varied so much and was expected to give a misleading representation of their activity. Although Newbold et al. (2015) noted that predation activity is likely associated positively with cell size within Entodiniomorphida, cell size per se oversimplifies this relationship because larger Isotrichidae apparently have much less predation activity compared with small Entodinium. Thus, quantitative measurement of biomass per se will not necessarily represent ecological differences among a range of protozoal populations seen within the rumen (Kittelmann et al., 2016).

A method combining ready ease of distinction based on taxonomy, typically either by standard distinction of generic cell counts or 18S rRNA gene copies (Kittelmann et al., 2015), with protozoal volume offers potential to better explain variation in studies designed to assess interactions between protozoa, bacteria, and archaea. Quantitative videographic approaches also reduce bias toward increased protozoal biomass associated with bacterial and archaeal contamination compared with protozoal standards isolated from the rumen (Sylvester et al., 2005). Moving from discrete and somewhat subjective scoring protocols, measurement of protozoal volume has been limited in efficacy to date because of its reliance on 2-dimensional measurements and an assumed third dimension (depth). Microscopic observation of live cells indicates a flattened or tapered morphology, revealing limitations of previously published volume estimation formulas (Table 1) using common cylindrical derivations (Teather et al., 1984; Dehority, 2010). Although derived to account for this discrepancy, even genera-specific equations use an assumed (rather than directly measured) depth (Clarke et al., 1982). Thus, it would be ideal to capture images of live protozoa to measure depth. Although their speed has previously been considered a deterrent to still image quality (Nam et al., 2009), image resolution has advanced enough since then to reconsider this limitation.

Protozoa of family Isotrichidae migrate in search of sugars and small starch granules, and their motility and chemotaxis have been known for some time (Dehority, 2003). In contrast, those within order Entodiniomorphida also have chemotaxis (but without the migration ecology) that should help maintain their association with the particulate phase in the rumen (Firkins et al., 2007). Both groups have complex but differing chemosensory signaling pathways targeting both glucose and peptides (Diaz et al., 2014a). Assessment of protozoal motility has been the simplest metric of chemotactic or chemorepellant (peptides are sometimes chemorepellant to Isotrichidae) response to treatment, traditionally using some form of transparency tracing from computer or video monitors (Leick et al., 1997; Diaz et al., 2014a). However, the labor associated with these techniques limits the duration of observation (Leick et al., 1997) or sample size (Diaz et al., 2014a). Highthroughput analyses for protozoal motility would likely advance our understanding of how differing protozoal inhibition methods influence ruminal activity, thus potentially explaining variable responses to protozoal suppression approaches (Hristov et al., 2013).

Ye (2013) dosed continuous culture fermentors with monensin (MON) with or without an essential oil combination of cinnamaldehyde and garlic oil (CIN; CinnaGar, Provimi North America, Brookville, OH), noting that CIN did not change protozoa counts; in contrast, estimates of protozoal volume using the cylindrical formula (Teather et al., 1984; Dehority, 2010) were increased by CIN whereas N:cell ratio decreased. Typically, cell size has been positively correlated with N:cell ratio (Weller and Pilgrim, 1974). However, a potential role for the apparent mode of action of CIN 
by Ye (2013) might be a result of changed cell volume but also could result from increased contamination of dietary or bacterial protein in the protozoal fraction. Thus, Ye (2013) provides an ideal example of how ruminant nutrition studies would benefit from videographic approaches that can distinguish potential changes in protozoal volume without the artifact contamination that can limit the gravimetric and filtration approaches typically used to quantify protozoal N:cell. Complete recovery of all protozoal cells, including those that pass through the smallest $(10-\mu \mathrm{m})$ filter (Sylvester et al., 2005), without corresponding feed contamination (Sylvester et al., 2009) is a challenge.

We propose that use of the free National Institutes of Health (Bethesda, MD) image analysis program ImageJ (Schneider et al., 2012) would allow more accurate high-throughput volume estimation via high-definition video in which rotating protozoa reveal a third dimension that can be captured as a still image. We replicated the previous experiment by Ye (2013) in batch cultures with the objective of improving our understanding of the effect of CIN on protozoal activity in the rumen. We hypothesize that, because cells naturally settle in counting chambers on their flatter side, our ability to accurately measure depth would decrease estimations of cell volume compared with previously published estimates. Further, protozoal motility would be observed in conjunction with inhibitor dosing of MON or CIN, or their combination, to protozoa in batch culture to screen for possible effects of treatment on protozoal activity. Because of the lack of protozoal size measurements in many studies, simulation of potential changes in protozoal volume from previous publications was considered the only option to demonstrate the potential utility of this new volume approach. Therefore, using previously published literature reporting quantification of protozoal counts, 3 simulations were derived to demonstrate how this improved technique could aid our understanding of (1) severe protozoal suppression in the rumen, (2) distributions of normal protozoal populations, and (3) the role of among-animal differences.

\section{MATERIALS AND METHODS}

\section{Experiment 1}

Rumen fluid was collected from 2 rumen-cannulated lactating Jersey cows at The Ohio State University's Waterman Dairy Center $2 \mathrm{~h}$ after feeding and strained through 2 layers of cheesecloth on site (Dehority, 1984). Animals were fed a common diet and maintained in accordance with The Ohio State University's animal care and use guidelines. Samples were maintained at $39^{\circ} \mathrm{C}$ throughout collection, transportation, and for the duration of the experiment. Following transport to the laboratory ( $<30 \mathrm{~min}$ from start of collection), each sample was diluted 1:1 with Simplex type buffer, as in Denton et al. (2015), and incubated for $45 \mathrm{~min}$ in a previously warmed separatory funnel before aspirating floating (flocculating) particulates.

After removing as much feed as possible via flocculation and aspiration, $30 \mathrm{~mL}$ of inoculum was distributed anaerobically into tubes containing preweighed treatments. The 4 treatments included (1) control (feed only), (2) feed $+0.0043 \%$ CIN (on a DM basis), (3) feed $+2.82 \mu M \mathrm{MON}$, and (4) feed + CIN + MON (in the same concentrations previously noted). Treatment concentration was consistent with the study previously conducted by Ye (2013). An N-free diet was provided to facilitate measuring N:cell without bias for a parallel experiment. To each tube, we added $0.5 \mathrm{~g}$ of purified diet consisting of $70 \%$ cellulose (Sigmacell 20, Cat. \#S3504, Sigma-Aldrich Co., St. Louis, MO), $25 \%$ potato starch (Cat. \#9005-25-8, Sigma-Aldrich Co.), and 5\% glucose (Cat. \#50-99-7, ACROS Organics, Thermo Fisher Scientific, Waltham, MA).

The experiment consisted of 4 treatments and 3 time points, with each conducted in duplicate blocks for a total of 24 tubes per each of 2 replications. Replications were performed on 2 separate days from the same 2 cows. At 0,3 , and $6 \mathrm{~h}$ after initial inoculation, tubes were inverted 5 times and then a $40-\mu \mathrm{L}$ subsample was taken from each and placed on a $0.1-\mathrm{mm}$ stage micrometer, covered with a glass coverslip, and immediately recorded. This procedure minimized oxygen exposure to any one sample but resulted in consistent exposure of the surface of samples to the atmosphere. Using a procedure developed in a preliminary experiment for capturing video of live protozoa, videos were captured starting with a video centered on the stage micrometer and then progressing in a serpentine pattern, first left, then down, then right, then up, and then left for a total of 9 videos, each with a 10-s duration, equally distributed in a $3 \times 3$ grid under the coverslip. Video was captured with a Nikon D50 digital single-lens reflex camera (Nikon Inc., Melville, NY) that was mounted to a trifocal microscope using a piece of black $3.8-\mathrm{cm}-$ diameter polyvinyl chloride tubing.

Videos were imported to ImageJ in grayscale (Schneider et al., 2012) and analyzed for motility using the Tetratracker plugin, shared by T. Hennessey (State University of New York, Buffalo; personal communication), modified from the ImageJ plugin "wrMTrck" to autodetect cell edges in binary and track movement of multiple objects. Cell tracking through ImageJ is similar to that described by Hennessey and Lampert (2012). The image conversion process is described in Supplementary File S1 (https://doi.org/10.3168/ 
jds.2017-13513), Figure S1, and parameters to select against diet particles are listed in Table 2. Briefly, conversion of grayscale video (Figure S1A), via red threshold setting (Figure S1B), to true binary (Figure $\mathrm{S} 1 \mathrm{C}$ ) enabled edge detection. A close-up view of the transition of cell coloring is given in Figure S2 in Supplementary File S1 (https://doi.org/10.3168/jds.2017 -13513). Optimizing the filtering process was needed for various rumen samples that contained protozoa in a matrix of undegraded feed particles based on size, but Brownian motion also allowed these particles to have movement that interfered with assessment of motility. Increasing the minimum and decreasing the maximum pixel size of object recognition limits eliminates diet particles that are smaller than the smallest protozoa or larger than the largest nonmotile protozoa, respectively. Selecting limits for maximum speed and directional change reduced false positive identification of protozoa of similar dimensions as shadowed particulates traversing the field of view in one frame. The result is a binary video of protozoa swimming, with labels enabling ease of tracking and manual quality checks (Supplementary File S1, Figure S1D). Motility estimates were average speed of all protozoa over all tracks, direction change, average cell area, and average displacement (travel between 2 pairs of $\mathrm{x}, \mathrm{y}$ coordinates per second) for an average of 40 cells per video. Each replicate tube had a corresponding stage micrometer video, which uniquely set the scale for conversion of pixels to micrometers.

\section{Experiment 2}

ImageJ includes ellipse measurement tools that were compared with manual outlining of the perimeter of protozoal cells (excluding cilia and spines). To verify the accuracy of the ellipse tool compared with hand-drawn ellipses on protozoa, using hand-drawn perimeters of mixed protozoa (genera Entodinium, Epidinium, Ophyroscolex, and family Isotrichidae) from still frames at their widest and narrowest dimensions, the area was computationally derived by ImageJ based on pixels and compared with the areas derived by its respective ellipse formula ( $\pi a b$ or $\pi a c$, where $a=1 / 2$ length, $b=1 / 2$ width, and $c=1 / 2$ depth). Based on regression analysis, only Entodinium (Supplementary File S2A; https://doi.org/10.3168/jds.2017-13513) had a significant regression coefficient (for depth); even so, the coefficient of determination (squared correlation coefficient) $\left(\mathbf{r}^{2}\right)=0.02$ in that residual regression documented high agreement between methods. Even though some genera were not well represented by their abundance in our ruminal fluid samples, the general agreement among all 4 taxa, including the large vari-
Table 2. Criteria for ImageJ (National Institutes of Health, Bethesda, $\mathrm{MD})$ plugin detection of protozoa

\begin{tabular}{lc}
\hline Criterion & Limit value \\
\hline Minimum object area $\left(\mu \mathrm{m}^{2}\right)$ & 251 \\
Maximum object area $\left(\mu \mathrm{m}^{2}\right)$ & $2.30 \times 10^{4}$ \\
Maximum speed $(\mu \mathrm{m} / \mathrm{s})$ & 259 \\
Maximum area change $(\%)$ & 100 \\
Minimum track length $(\mathrm{s})$ & 2 \\
Threshold for turn (angle, $\left.^{\circ}\right)$ & 5 \\
Minimum direction change (proportion) & 0.2 \\
\hline
\end{tabular}

ability in sizes, supports subsequent usage of the ellipse tool for subsequent work.

An ellipsoid equation was used to estimate protozoal volume: $(4 / 3) \pi a b c$, where $a=1 / 2$ length, $b=1 / 2$ width, and $c=1 / 2$ depth. When applied to a rotating cell, the ellipse can be used to differentiate between width and depth, which is a ratio not constant among protozoal genera (Williams and Coleman, 1997) and that potentially varies between ruminants based on diet, additives, or other conditions. Output from the ellipse measurement within ImageJ provides a Feret diameter, which is defined as the greatest distance on the longitudinal axis within the ellipse. A secondary Feret diameter, which is the greatest width perpendicular to the established longitudinal axis, is also reported from protozoa that rotate during swimming (Supplementary File S1, Figure S3). Trained observers placed an ellipse for all cells in the field of view at both the widest and narrowest view of each cell during a swimming track for each video, yielding 2 matching measurements of length (2a) and 1 measurement each of width $(2 b)$ and depth $(2 c)$.

Video recordings from experiment 1 were used to select protozoal cells randomly from 3 diversely shaped protozoal taxonomical groups (genus Epidinium, genus Entodinium, and family Isotrichidae). A laboratory culture of Epidinium caudatum (courtesy of B. Dehority; The Ohio State University, Wooster) was used to capture additional video for volume estimations on genus Epidinium because of its low incidence in the in vivo samples previously collected for experiment 1 . The coefficients by Clarke et al. (1982) were the only measurements in Table 1 that used density measurements to adjust a cylinder for depth, so these genera-specific coefficient-based volume estimates were chosen for residual regression analysis compared with the proposed ellipsoid method.

\section{Statistical Analysis}

Data from experiment 1 were analyzed using the Mixed procedure of SAS (version 9.4; SAS Institute Inc., Cary, NC) in a randomized complete block design 
that included the random blocking effect of inoculation and the fixed effects of MON, CIN, and MON $\times$ CIN . Data were covariate-adjusted for dependent variable mean within treatment $\times$ replicate inoculation at 0 $\mathrm{h}$, and $\mathrm{h} 3$ and 6 were treated as repeated measures. Significance was declared at $P \leq 0.05$; and trends, 0.05 $<P \leq 0.10$.

For experiment 2, the areas that were derived manually (from hand drawing) were considered the observed values, and those areas from the ellipse tool were considered predictions. Either observed or residuals (observed - predicted) were $\mathrm{Y}$ variables regressed against predicted values (X variables) using the REG procedure of SAS (version 9.4; SAS Institute Inc.). Volume estimates using the equation from Clarke et al. (1982) were used as the observed values, and ellipsoid volumes were considered predicted. The residuals ( $\mathrm{Y}$ variable) were regressed against predicted ( $\mathrm{X}$ variable) values using the REG procedure of SAS, with the $\mathrm{X}$ values for each protozoal group centered around their respective means: $\left(\mathrm{X}_{\mathrm{i}}-\overline{\mathrm{x}}\right)$ (St-Pierre, 2003). Slope bias was assessed by linear regression $(P \leq 0.05$ different from zero); and mean bias, by the intercept of linear regression $(P \leq$ 0.05 different from zero).

\section{RESULTS AND DISCUSSION}

\section{Experiment 1}

Optimizing Motility Analysis. Preliminary testing of a subset of videos revealed difficulty in discriminating nonmotile protozoa from diet particulate matter. Therefore, we investigated a series of parameters from ImageJ to optimize detection and tracking of protozoal cells as distinctly different from background feed particles while minimizing the nondetection of nonmotile protozoa. Practical size limits to differentiate feed particles and protozoa are reported in Table 2 in micrometers, which must be converted to pixels for input to ImageJ. Minimum track length was 60 frames (2 s), minimum area of detected cells was $251 \mu \mathrm{m}^{2}$, maximum cell area was limited at $2.30 \times 10^{4} \mu^{2}$, and maximum speed was limited to $258 \mu \mathrm{m} / \mathrm{s}$. If undetected during video capture, Brownian motion can be digitally corrected by creating a background image compilation of all frames and then subtracting this compilation from each frame in the video, leaving only cells that are actively swimming.

In our application, the minimum object area was the most challenging limit to set on the autodetection plugin for ImageJ. If minimum protozoa size is not carefully monitored, the observer risks false negatives for very small protozoa and thereby biasing the computed mean area of a sample from a treatment that is ex- pected to shrink protozoal cell diameter. For example, Charonina ventriculi is normally a minor member of the rumen (Towne and Nagaraja, 1990), but C. ventriculi (verified by B. Dehority, personal communication) has been enriched to nearly 20 to $30 \%$ of protozoa cell counts in dual-flow continuous culture (Wenner, 2016) or other unique rumen situations (Dehority and Mattos, 1978; Dennis et al., 1983; Kittelmann et al., 2015). If present, protozoa of this size would be difficult to detect automatically using the current parameters. The combination of swimming speed and object size limits correct identification of the smallest protozoa; thus, the autodetection procedure presented here is more robust when parameters are manually verified for each experiment by comparing data output with personal observation of protozoa.

When originally viewed in grayscale, the biofilm may appear a nonfactor for artifact inclusion as nonmotile protozoa, but conversion to binary black and white pixilation tends to aggregate large areas of biofilm. Although small biofilm aggregates can be removed similar to feed particles above, larger biofilm areas tend to interfere with protozoa detection. Some large entodiniomorphids also approached the maximal object size limit of $2.30 \times 10^{4} \mu^{2}$ used in our studies, but these incidences were infrequent, occurring in $<0.5 \%$ (data not shown) of total protozoa and will need to be corrected in future plug-in updates. Unfortunately, the maximal object size limited our ability to autodetect large protozoa (e.g., Polyplastron), but there were few in the current study. Future researchers would need to monitor and possibly adjust settings if these very large protozoa made up a significant proportion of the ciliate population.

Maximum speed settings are much more easily determined in single cultures than in more complex ruminal samples because there is wide disparity in swimming speed between large and small protozoa, fed or fasted states, or based on prolonged sensitivity to oxygen. Yet, these factors do not deter assessment of chemotaxis (Diaz et al., 2014b), even in videos with mixed protozoa from ruminal samples (Diaz et al., 2014a), so maximum speed of the current approach primarily serves to limit when the plugin detects multiple particles of identical size in a frame and randomly switches the associated label in the next frame. Random switching of cell labels occurred only with smaller dietary particles and was easily identified in track paths after analysis. Limiting maximum particle speed before analysis prevents unnecessary manual sorting and exclusion of dietary particles after analysis.

While swimming through the liquid sample on the slide, protozoa inevitably collide with each other, small particles, and any large feed particles not removed dur- 
Table 3. Least squares means for protozoal motility analysis after rumen fluid was incubated without $(-)$ or with $(+)$ monensin $($ MON), CinnaGar (CIN), or both for either 3 or 6 h (experiment 1$)^{1}$

\begin{tabular}{|c|c|c|c|c|c|c|c|c|}
\hline \multirow[b]{2}{*}{ Item } & \multicolumn{2}{|c|}{$\mathrm{MON}-$} & \multicolumn{2}{|c|}{$\mathrm{MON}+$} & \multirow[b]{2}{*}{ SEM } & \multicolumn{3}{|c|}{ Contrast $^{2}$} \\
\hline & $\mathrm{CIN}-$ & $\mathrm{CIN}+$ & CIN- & $\mathrm{CIN}+$ & & MON & CIN & $\mathrm{CIN} \times \mathrm{MON}$ \\
\hline Average speed $(\mu \mathrm{m} / \mathrm{s})$ & 243 & 211 & 138 & 183 & 13 & $<0.01$ & NS & $<0.01$ \\
\hline Displacement $(\mu \mathrm{m} / \mathrm{s})$ & 73.2 & 62.5 & 48.4 & 59.8 & 3.4 & $<0.01$ & NS & $<0.01$ \\
\hline Direction change (relative proportion) & 0.423 & 0.441 & 0.445 & 0.460 & 0.014 & 0.10 & NS & NS \\
\hline Average area $\left(\mu \mathrm{m}^{2}, \times 10^{3}\right)$ & 1.95 & 1.59 & 1.80 & 1.65 & 0.12 & NS & 0.05 & NS \\
\hline Displacement $(\mu \mathrm{m} / \mathrm{s})$ & 73.4 & 70.7 & 49.0 & 50.4 & 6.2 & $<0.01$ & NS & NS \\
\hline Direction change (relative proportion) & 0.449 & 0.437 & 0.450 & 0.476 & 0.021 & NS & NS & NS \\
\hline Average area $\left(\mu \mathrm{m}^{2}, \times 10^{3}\right)$ & 1.95 & 2.00 & 1.64 & 1.61 & 0.28 & NS & NS & NS \\
\hline
\end{tabular}

${ }^{1}$ Treatments were MON (2.82 $\mu M$ monensin), CIN (0.0043\% CinnaGar on a DM basis; Provimi North America, Brookville, OH), or the combination of MON plus CIN.

${ }^{2} P$-values reported for the main effects of MON or CIN and their interaction $(\mathrm{CIN} \times \mathrm{MON})$. NS $=P>0.10$. There was no interaction of treatment by hour $(P>0.20)$.

ing flocculation. Although these obstacles are present in the rumen, digital removal is needed to accurately gauge swimming speed, which varies with dietary treatments. Protozoal collisions change the shape detected by cell outline and can cause ImageJ to temporarily misidentify colliding objects as one new cell rather than a combination of the previous 2 cells or objects. The shape change during collisions can exceed $100 \%$ increase in cell area at the moment of impact of protozoa with particles or between 2 protozoa, especially if colliding protozoa are of different genera. By eliminating shape change detection (i.e., maximum area change was set to 100\%), ImageJ eliminates label changes during collisions of 2 protozoa. Finally, all objects tracked with a direction change proportion of $<0.2$ (ratio of current direction to previous direction) were removed from consideration based on comparison of $n>200$ cell labels and the frequency of biologically unrealistic straight-line travel associated with object detection error in ImageJ (authors' personal observation). When auto-detected cells moved in straight-line segments with severe direction change between intervals, these incidences were typically from feed particles of matching size rotating in parallel across the field of view and incorrectly assumed to be making rapid and severe travel speed and angle changes. Our direction change criteria eliminated particles with straight-line travel that fit size and speed parameters for protozoa but, instead, were specks or shadows in the images.

Using Video Capture to Assess Protozoal Motility as Affected by Inhibitors. There were no treatment $\times$ time interactions $(P>0.10)$ for any variables in this study. At $3 \mathrm{~h}$ post-inoculation, we detected a treatment interaction $(P<0.01)$ for average speed such that CIN attenuated the inhibition by MON (Table 3). At $6 \mathrm{~h}$ post-inoculation, there was a main effect of added MON such that it decreased ( $P$ $<0.01$ ) average speed by $79.2 \mu \mathrm{m} / \mathrm{s}$ compared with treatments without MON. Similar results at 3 and $6 \mathrm{~h}$ were detected for displacement, which is the net distance from beginning to end, documenting no shift in motility pattern as would be detected during chemotaxis (Diaz et al., 2014a). For cell direction change at $3 \mathrm{~h}$ post-inoculation, the main effect of MON tended $(P=0.10)$ to increase direction change proportion by 0.0205 compared with treatments without MON, but there was no effect $(P>0.10)$ of treatment on direction change at $6 \mathrm{~h}$ post-inoculation. The average main effect of CIN decreased $(P=0.05)$ average cell area at $3 \mathrm{~h}$ post-inoculation compared with the average of those treatments without CIN $\left(256 \mu \mathrm{m}^{2}\right)$, but we detected no effect $(P>0.10)$ at $6 \mathrm{~h}$ post-inoculation.

The inhibition of protozoal activity by MON, as determined by cell counts and fermentation patterns, was previously described (McGuffey et al., 2001; Russell, 2002). The response was predicted (based on results from non-rumen protozoa) to result from disrupted function of digestive vacuoles and was eliminated or lessened by adaptation of protozoa after several transfers in batch culture (Sylvester et al., 2009). Our short-term responses to MON were manifested through decreased protozoal speed and directional swimming. Combining the effect of CIN decreasing cell area at $3 \mathrm{~h}$ post-inoculation, CIN apparently shrinks cell size and attenuates the effect of MON on protozoal metabolic activity, explaining the interactions for both speed and displacement. Essential oils have decreased methanogenesis in vivo and in batch cultures, typically explained by disruption of cell membranes (Benchaar and Greathead, 2011); yet, there are limited reports of essential oil activity against protozoa specifically. Ye (2013) reported that the main effect of MON increased 
Table 4. Mean volume and standard deviation for 4 previously published protozoal volume estimation equations and the proposed ellipsoid method for genus Entodinium, family Isotrichidae, and genus Epidinium ${ }^{1}$

\begin{tabular}{llcc}
\hline Family or genus & Method & $\begin{array}{c}\text { Volume } \\
\left(\times 10^{5} \mu \mathrm{m}^{3}\right)\end{array}$ & $\begin{array}{c}\mathrm{SD} \\
\left(\times 10^{5} \mu \mathrm{m}^{3}\right)\end{array}$ \\
\hline $\begin{array}{l}\text { Entodinium } \\
(\mathrm{n}=100)\end{array}$ & Harmeyer and Hill (1964) & 1.11 & 0.62 \\
& Clarke et al. (1982) & 0.991 & 0.517 \\
& Teather et al. (1984) & 0.969 & 0.519 \\
Dehority (2010) & 1.10 & 0.56 \\
Isotrichidae & Ellipsoid (proposed herein) & 0.798 & 0.399 \\
$(\mathrm{n}=30)$ & Harmeyer and Hill (1964) & 18.2 & 7.1 \\
& Clarke et al. (1982) & 25.2 & 6.8 \\
& Teather et al. (1984) & 51.9 & 26.0 \\
Epidinium & Dehority (2010) & 36.2 & 12.0 \\
(n=63) & Ellipsoid (proposed herein) & 25.4 & 7.2 \\
& Harmeyer and Hill (1964) & 1.77 & 1.33 \\
& Clarke et al. (1982) & 3.17 & 1.44 \\
& Teather et al. (1984) & 6.13 & 1.50 \\
& Dehority (2010) & 3.69 & 1.24 \\
& Ellipsoid (proposed herein) & 2.45 & 0.79 \\
\hline
\end{tabular}

${ }^{1}$ Method descriptions are detailed in Table 1.

generation time by $5.5 \mathrm{~h}$ in continuous cultures that had been adapted for $7 \mathrm{~d}$ and with similar protozoal counts as the control. In the same study, Ye (2013) reported that CIN tended $(P<0.07)$ to decrease protozoal counts in fermentors but had similar generation time as controls. The inhibitory effect of CIN on area per cell in the present study with unadapted protozoa was probably mediated through cell membrane disruption, possibly altering response of protozoa toward known MON toxicity (Karnati et al., 2009a).

\section{Experiment 2}

As discussed previously for methodology, the areas of both the widest and narrowest plane supported the use of the ellipse shape to represent a variety of ruminal protozoa across a large range of sizes (Supplementary File S2; https://doi.org/10.3168/jds.2017-13513). Because of the small number of observations for Epidinium, a single culture of Ep. caudatum was used for subsequent volume measurements, which incorporated the elements of both area planes.

Estimates of volume from several equations are listed in Table 4, including the method derived by Clarke et al. (1982), which was chosen for comparison. Regression of residuals versus predicted values for genus Entodinium had significant slope $(P<0.01)$ and mean $(P<0.01)$ biases (Figure 1). Genus Entodinium offered the greatest challenge to previous estimates of protozoal volume, likely because of the broad size distribution of this predominant genus (Dehority, 2003). A significant mean bias indicated that our ellipsoid method decreased estimated cellular volume by $19.5 \%$ for Entodinium spp. compared with the method derived by Clarke et al. (1982). Slope bias for Entodinium spp. indicated a varying effect of protozoal volume estimation that widens as cells increase in size. Larger cells would also have increased width and thus potential for increased disparity of estimated depth versus true depth, an effect most clearly observed in Entodinium spp. that are swimming.

Regression analysis of residuals versus predicted values for family Isotrichidae revealed no $(P>0.10)$ mean bias, indicating that previous estimation methods utilizing a fixed coefficient yielded similar volume estimations. The lack of bias is likely because Isotrichidae are teardrop-shaped and more uniformly rounded. Williams and Coleman (1997) explicitly describe Isotrichidae as ellipsoidal in shape. Slope for Isotrichidae regressions tended $(P=0.08)$ to be different from zero (Figure 2$)$, indicating the potential for a variable relationship of volume estimates over the range of size. The potential size dependence could be due to the limited number of cows sampled and needs to be investigated further but requires access to more cows with greater diversity and abundance of populations of genus Dasytricha (average $58 \mu \mathrm{m}$ long $\times 27 \mu \mathrm{m}$ wide) versus genus Isotricha (average $123 \times 65 \mu \mathrm{m}$ length and width; Williams and Coleman, 1997).

Regression of residuals versus predicted values for genus Epidinium revealed both slope $(P<0.01)$ and mean $(P<0.01)$ biases (Figure 3), indicating that previous estimates of Epidinium volume (Clarke et al., 1982) should be decreased by our ability to measure the third dimension and its downstream effect on estimates of cell volume via the ellipsoid equation. Epidinium spp. may change shape in single culture under less challenging conditions for survival; certainly, the loss of spines has changed our perception of species definitions (Dehority, 2006). The limited frequency of Epidinium in the 


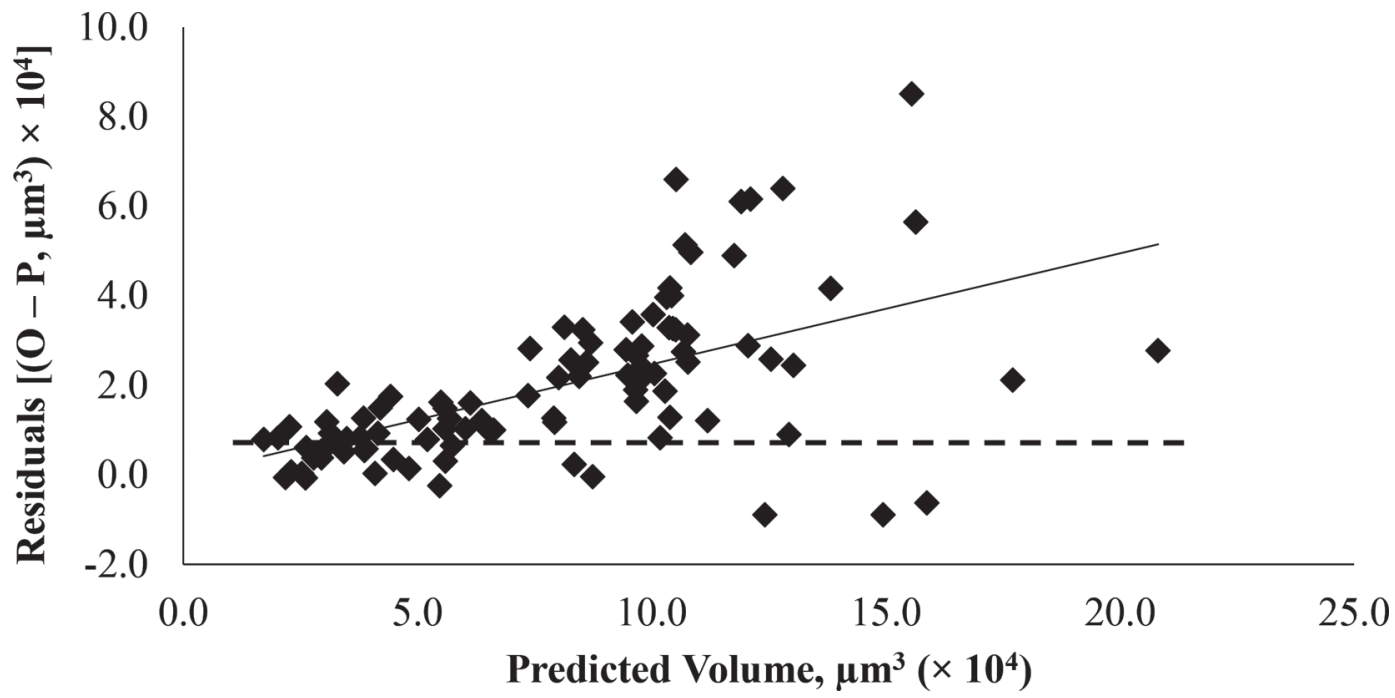

Figure 1. Regression of residuals versus ellipsoid predicted protozoal volume for genus Entodinium (experiment 2). Ellipsoid values are predicted $(\mathrm{P})$, and genera-specific coefficient estimations from Clarke et al. (1982) are observed (O). The dashed line represents the mean bias (intercept) of $1.97 \times 10^{4} \mu^{3}\left(\mathrm{SE}: 1.48 \times 10^{3}\right)$. Predicted values $\left(\mathrm{X}_{\mathrm{i}}\right)$ are centered to their overall mean $\left(7.98 \times 10^{4}\right)$. The regression equation (representing linear bias; solid line) followed the formula: $\mathrm{Y}=0.248( \pm 0.037)\left(\mathrm{X}_{\mathrm{i}}-7.98 \times 10^{4}\right)+1.97 \times 10^{4}\left( \pm 1.48 \times 10^{3}\right) ; \mathrm{n}=100 ; \mathrm{r}^{2}=0.31$. Both mean and slope were different $(P<0.01)$ from 0 .

rumen of cannulated cows available at our institution required the use of a single culture of Ep. caudatum; this among-cow disparity in Epidinium prevalence at our institution has been described previously (Sylvester et al., 2004). Genus Epidinium is absent in the rumen of animals that contain the genus Polyplastron, apparently because of cannibalism (Dehority, 2003). Because protozoal counts are far more commonly distributed by genus than by species in the scientific literature, no single formula apportioning a constant width:depth is likely to describe their volume consistently. In contrast, the ellipsoid function derives a mean volume that is weighted proportionately to changes in both width and measured (rather than assumed constant) depth among

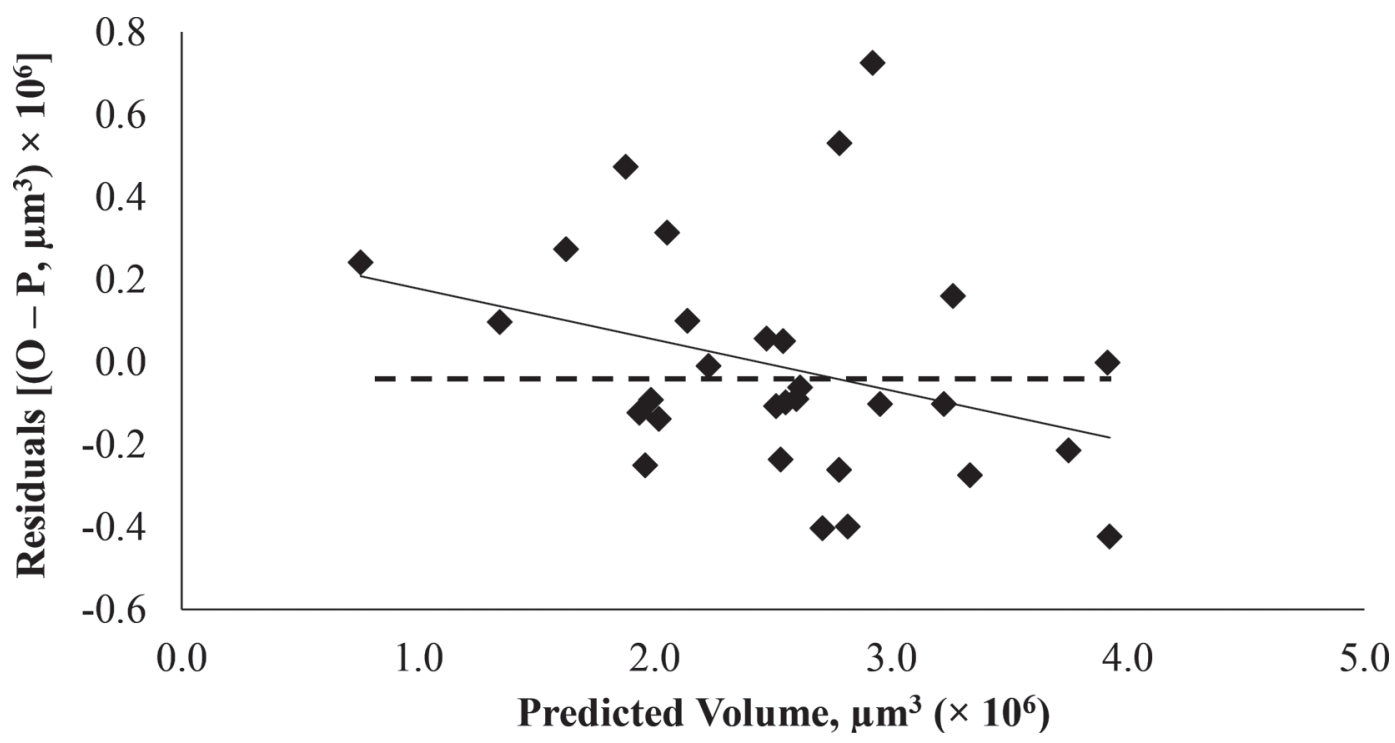

Figure 2. Regression of residuals versus ellipsoid predicted protozoal volume methods for family Isotrichidae (experiment 2). Ellipsoid values are predicted $(\mathrm{P})$, and genera-specific coefficient estimations from Clarke et al. (1982) are observed (O). The dashed line represents the mean bias (intercept) of $-1.21 \times 10^{4} \mu^{3}$ (SE: $\left.4.86 \times 10^{4}\right)$. Predicted values $\left(\mathrm{X}_{\mathrm{i}}\right)$ are centered to their overall mean $\left(2.54 \times 10^{6}\right)$. The regression equation (representing linear bias; solid line) followed the formula: $\mathrm{Y}=-0.124( \pm 0.069)\left(\mathrm{X}_{\mathrm{i}}-2.54 \times 10^{6}\right)-1.21 \times 10^{4}\left( \pm 4.86 \times 10^{4}\right) ; \mathrm{n}=32 ; \mathrm{r}^{2}=$ 0.10 . There was no mean bias $(P>0.10)$, but slope tended $(P=0.07)$ to be different from 0 . 


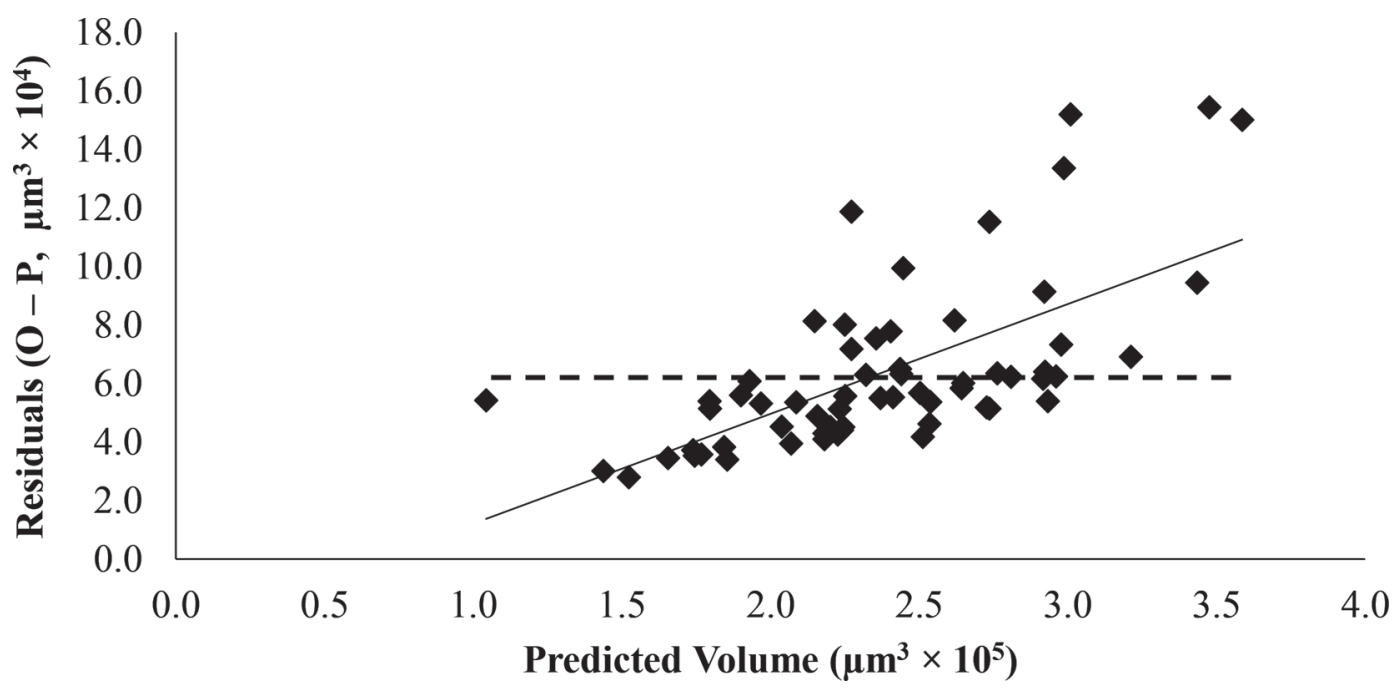

Figure 3. Regression of residuals versus ellipsoid predicted protozoal volume for genus Epidinium (experiment 2). Ellipsoid values are predicted (P), and genera-specific coefficient estimations from Clarke et al. (1982) are observed (O). The dashed line represents the mean bias (intercept) of $6.65 \times 10^{4} \mu^{3}\left(\mathrm{SE}: 0.281 \times 10^{4}\right)$. Predicted values $\left(\mathrm{X}_{\mathrm{i}}\right)$ are centered to their overall mean $\left(2.45 \times 10^{5}\right)$. The regression equation (representing linear bias; solid line) followed the formula: $\mathrm{Y}=0.375( \pm 0.056)\left(\mathrm{X}_{\mathrm{i}}-2.45 \times 10^{5}\right)+6.65 \times 10^{4}\left( \pm 0.28 \times 10^{4}\right) ; \mathrm{n}=64 ; \mathrm{r}^{2}=0.43$. Both mean and slope were different $(P<0.01)$ from 0 .

genera, including those for which no formula was derived or that might change morphology according to dietary conditions.

Harmeyer and Hill (1964) previously proposed the use of an ellipsoid with the assumption that width and depth of the cell were equivalent, but they substituted length for a coefficient $\times$ width: cell volume $\left(\mu \mathrm{m}^{3}\right)=$ $0.8099 \times$ width $^{3}$. Harmeyer and Hill's (1964) equation had limited use (Towne and Nagaraja, 1990; Towne et al., 1990), possibly because it was published in German. A more integrative approach estimates protozoal volume by integrating miniature cylinders with variable radii based on distance from longitudinal axis to the cell membrane (Sieracki et al., 1989). Such an approach would also inflate volume estimation, owing again to a lack of knowledge about the third dimension of the cell. Confocal microscopy would be ideal, but time and cost limit sample size and practicality for the heterogeneous mix of protozoa in vivo.

\section{Implications of New Estimates for Protozoal Volume}

Improvements in our ability to detect volume differences in rumen protozoa by videography might have a variety of downstream effects on animal nutrition and our interpretations of rumen microbial research. Although some literature estimates are available, they are primarily from equations that assume protozoa are cylinders; our results from experiment 2 indicate that such equations likely overestimate volume. That the microbial population represents 10 to $20 \%$ of rumen liquid and protozoa may account for $50 \%$ of microbial biomass are common generalizations that have been propagated over the decades (Czerkawski, 1984; Jouany, 1991). The estimates for microbial population volume and that for protozoal biomass appear to originate from Hungate et al. (1971), who counted and assigned approximated volumes to bacteria and protozoa of varying discrete sizes. Reported protozoal volumes are not consistent with more recent publications, warranting a fresh analysis and supporting our proposed new method for nutrition studies. For example, Entodinium caudatum is listed at a volume of $96 \mu \mathrm{m}^{3}$ (see Table 5); however, E. caudatum was recently more realistically described as being $28 \mu \mathrm{m}$ wide and $35 \mu \mathrm{m}$ long (Belanche et al., 2012). Assuming a commonly observed depth-towidth ratio of $0.70( \pm 0.09$, observed in our current study for genus Entodinium), cell depth for an average E. caudatum can be estimated to be $20 \mu \mathrm{m}$. An ellipsoid estimate of volume resulting from these values $(4 / 3 \times \pi \times 14 \times 17.5 \times 10)$ would be $10,263 \mu \mathrm{m}^{3}$. Besides being much higher than the value in Table 5, this volume would increase by $12.9 \%$ if the depth-to-width ratio were merely increased to 0.79 , emphasizing the effect that small changes in depth assumptions can have on protozoal volume estimations. Using published cell dimensions (Williams and Coleman, 1997; Dehority, 2010; Belanche et al., 2012), we similarly estimate errors by Hungate et al. (1971) in Table 5 of 225 -fold for Entodinium spp., 400-fold for family Isotrichidae, and $>1,000$-fold for other larger protozoa. An apparent offsetting error of volume unit conversion by 1,000-fold in 
Table 5. Comparison of reported protozoal volume from Hungate et al. (1971) with ellipsoid estimated protozoal volume

\begin{tabular}{|c|c|c|c|c|c|c|c|c|}
\hline $\begin{array}{l}\text { Protozoa genus } \\
\text { or species }^{1}\end{array}$ & $\begin{array}{l}\text { Cell length } \\
\quad(\mu \mathrm{m})\end{array}$ & $\begin{array}{c}\text { Cell } \\
\text { width }^{2}(\mu \mathrm{m})\end{array}$ & $\begin{array}{c}\text { Cell } \\
\operatorname{depth}^{3}(\mu \mathrm{m})\end{array}$ & $\begin{array}{c}\text { Reported } \\
\text { volume }^{1}\left(\mu \mathrm{m}^{3}\right)\end{array}$ & $\begin{array}{c}\text { Ellipsoid } \\
\text { volume }^{4}\left(\mu \mathrm{m}^{3}\right)\end{array}$ & $\begin{array}{l}\text { Volume } \\
\text { error factor }\end{array}$ & $\begin{array}{c}\text { Count } \\
\text { (cells/mL) }\end{array}$ & $\begin{array}{l}\text { Volume } \\
(\mu \mathrm{L} / \mathrm{mL})\end{array}$ \\
\hline \multicolumn{9}{|l|}{ Entodinium spp. } \\
\hline E. vorax & 95 & 68 & 48 & 387 & 161,005 & 446 & 3.3 & 0.53 \\
\hline Dasytricha spp. & 72 & 37 & 37 & 128 & 48,169 & 403 & 14.9 & 0.72 \\
\hline Isotricha spp. & 190 & 90 & 90 & 1,900 & 752,099 & 424 & 13.5 & 10.15 \\
\hline Polyplastron spp. & 320 & 220 & 154 & 2,200 & $5,676,662$ & 2,765 & 4.8 & 27.25 \\
\hline Ophryoscolex spp. & 330 & 140 & 140 & 1,800 & $3,160,869$ & 1,881 & 12.8 & 40.46 \\
\hline \multicolumn{8}{|c|}{ Total corrected volume (sum of all species) } & 101.70 \\
\hline \multicolumn{8}{|c|}{ Protozoal volume adjusted for shrinkage ${ }^{7}$} & 127.13 \\
\hline
\end{tabular}

${ }^{1}$ Protozoal speciation, reported cell volumes, and cell enumeration taken from Hungate et al. (1971).

${ }^{2}$ Published values for respective species length and width taken from Williams and Coleman (1997), Dehority (2003), and Belanche et al. (2012).

${ }^{3}$ Cell depth estimated for all protozoal genera or species by multiplication of width $\times 0.70$, as explained in text.

${ }^{4}$ Estimated volume by ellipsoid equation: $(4 / 3) \pi a b c$, where $a=1 / 2$ length, $b=1 / 2$ width, and $c=1 / 2$ depth.

${ }^{5}$ Error factor calculated by division of ellipsoid volume estimate by cell volume published in Hungate et al. (1971).

${ }^{6}$ Volume $(\mu \mathrm{L})$ occupied by protozoal cells in $1 \mathrm{~mL}$ of rumen fluid sampled. Volume was extrapolated by taking ellipsoid equation (footnote 4 ) and multiplying by cell count.

${ }^{7}$ Volume adjusted for shrinkage according to estimates of $20 \%$ for formaldehyde treatment of cells by Choi and Stoecker (1989).

that paper ultimately reduces the estimate of protozoal contribution to rumen microbial volume and biomass shown in Table 5 . Because of the considerable literature citations of that paper (at least 74 times), we recommend that microbial biomass fractions should be reevaluated under a variety of feeding conditions to update projections of nutritional implications on protozoal biomass and $\mathrm{N}$ contribution to metabolizable protein supply.

The effect of improved accuracy for quantifying protozoal volume can be demonstrated with simulated differences in volume (and theoretically protozoal activity) from 3 publications with divergent shifts in protozoal populations. In Reveneau et al. (2012), the authors noted that treatment of lactating cows with $5 \%$ coconut oil dramatically decreased $\log _{10}$ protozoal concentration (except for genus Epidinium). If the log of protozoa is converted to actual cell counts and multiplied by the percentage of protozoa in particular genera and ellipsoidal estimates of volume (Table 6), the effects of coconut oil on protozoal populations become more apparent, indicating a decrease in protozoal volume from greater than $10 \%$ of rumen liquid volume in the control diets to less than $1 \%$ of rumen liquid volume in the $5 \%$ coconut oil diets. However, despite the much lower cumulative protozoal volume, the estimated volume:cell actually increased as a result of a shift in protozoal populations.

In the second example, Belanche et al. (2012) comprehensively quantified protozoal cell dimensions from sheep by measuring subsamples within isotrichid-only or mixed protozoal populations. In an intricate meth- odological approach, protozoal cells were separated by a series of filter pore sizes $(80,60,45,35,20$, and 5 $\mu \mathrm{m})$. Those authors also reported DNA distribution in a companion paper (Belanche et al., 2014). Total protozoal cell volume estimated by the cylindrical method varied widely with total cell count when both were expressed as a proportion of the total rumen protozoal population in that report. We estimated protozoal volume using the currently proposed ellipsoid method in combination with the published DNA distributions and report the simulated results in Table 7. Consideration of methanogen DNA per protozoan volume rather than protozoan cell number did not solely support increased associated methanogens due to protozoa dimensions but more likely increased metabolism and production of available dihydrogen. This simulation documents the potential opportunity to include greater numbers of cells and greater accuracy of volume/cell in future studies. Cell counts have long been known to hide potential relationships associated with activity (Whitelaw et al., 1984), but this exercise demonstrates that activity also can vary nonlinearly with protozoal volume. Dehority (2010) noted that total cell volume (discussed as protoplasm) of all protozoa within a culture was proportional to substrate availability, regardless of the size (inversely related to number) of the various species or strains studied. Similarly, Sylvester et al. (2009) noted that the quantity of $18 \mathrm{~S}$ rDNA copies appeared roughly proportional to protein synthesis rate and increased proportionately with cell volume unless large protozoa (Ophryoscolex caudatus) had slower growth. As interest 
Table 6. Simulated protozoal volume differences in dairy cows treated either with or without Rumensin (Elanco Animal Health, Indianapolis, IN) in combination with either control or $5 \%$ coconut oil

\begin{tabular}{|c|c|c|c|c|}
\hline \multirow[b]{2}{*}{ Item } & \multicolumn{2}{|c|}{ Without Rumensin } & \multicolumn{2}{|c|}{ With Rumensin } \\
\hline & Control & Coconut oil & Control & Coconut oil \\
\hline$\overline{\text { Protozoa }^{1}\left(\times 10^{4} \text { cells } / \mathrm{mL}\right)}$ & 81.3 & 7.2 & 102.3 & 5.5 \\
\hline Entodinium & 70.4 & 4.9 & 92.2 & 3.8 \\
\hline Epidinium & 6.34 & 1.85 & 5.55 & 1.63 \\
\hline Diplodinium & 0.870 & 0.087 & 1.020 & 0.008 \\
\hline Ophryoscolex & 0.146 & 0 & 0.041 & 0 \\
\hline Isotricha & 2.02 & 0.37 & 1.82 & 0.07 \\
\hline Dasytricha & 1.53 & 0.01 & 1.66 & 0.00 \\
\hline Total cell volume ${ }^{2}\left(\times 10^{9}, \mu \mathrm{m}^{3} / \mathrm{mL}\right)$ & 97.2 & 11.8 & 108.2 & 7.6 \\
\hline Volume:cell ratio ${ }^{3}\left(\times 10^{5}{\mu \mathrm{m}^{3}}^{3} / \mathrm{mL}\right)$ & 1.20 & 1.64 & 1.06 & 1.38 \\
\hline
\end{tabular}

${ }^{1}$ Cell counts and relative proportion of protozoal genera taken from Reveneau et al. (2012).

${ }^{2}$ Total cell volume was calculated using ellipsoid method regression means (Figures 1, 2, 3) for Entodinium and Epidinium or using average cell length and width for Diplodinium from Williams and Coleman (1997), Ophyroscolex from Dehority (2003), and Isotricha and Dasytricha from Belanche et al. (2012), and are reported per milliliter of rumen fluid.

${ }^{3}$ Volume:cell ratio was calculated by dividing mean values for cell volume by mean cell count.

grows in DNA-based assessment of protozoal populations (Ishaq and Wright, 2014), protozoal rDNA copies could be scaled to protozoal volume to provide a more meaningful relationship to activity because both taxa and cell size would be represented.

In a third example, Kittelmann et al. (2016) evaluated methane emission of sheep characterized by their protozoal community type (A-, B-, O-, and mixed ABtypes) according to Eadie (1962). Although methane ranking by sheep was moderately successful, the authors were unable to correlate protozoal community types to methane production. Without cell counts, a working volume of protozoa per milliliter of rumen contents cannot be established, so some caution must be exercised with this simulation. However, Table 8 illustrates the vast difference in relative protozoal volume with various community types based upon a standardized cell count. Although community types in Kittelmann et al. (2016) differed very little by methane production, we simulated methane produced by relative protozoal volume to differ substantially among population types. Therefore, the ellipsoid method offers a potential opportunity to improve success in methane abatement strategies that involve protozoal suppression, which has been inconsistent so far (Hristov et al., 2013). Inclusion of our approach could provide some clarity and potential opportunity for future approaches.

Accounting for differences in protozoal volume among animals and diets would improve our understanding of protozoal ecology in the rumen. Karnati et al. (2007) previously discussed the role of accurate rumen liquid volume estimates for determining protozoal pool size and generation time of protozoa. Isotrichidae sequester in the ventral rumen post-inoculation (Dehority, 2003),

Table 7. Simulated protozoal volume and DNA per cell or per protozoal volume from ruminally cannulated sheep

\begin{tabular}{|c|c|c|c|c|c|c|c|}
\hline Item & 80 & 60 & 45 & 35 & 20 & 5 & $<5$ \\
\hline Large family Diplodiniinae & 74.5 & 51.4 & 18.4 & 0.8 & 0 & 0 & 0 \\
\hline Isotricha spp. & 16.1 & 37.3 & 36.6 & 20.5 & 3.6 & 1.2 & 0 \\
\hline Epidinium spp. & 2.9 & 6 & 27.3 & 33.9 & 10.3 & 0 & 0 \\
\hline Small Diplodiniinae & 4.5 & 4.3 & 16.6 & 38.5 & 31.2 & 0.9 & 0 \\
\hline Total protozoal volume ${ }^{2}\left(\times 10^{9} \mu \mathrm{m}^{3}\right)$ & 11.6 & 122.5 & 79.8 & 63.1 & 167.3 & 25.0 & 0.1 \\
\hline Protozoal genomic $\mathrm{DNA}^{3}$ (ng $/ 10^{9} \mu \mathrm{m}^{3}$ protozoal cell volume) & 0.320 & 0.036 & 0.054 & 0.070 & 0.027 & 0.176 & 26.755 \\
\hline Methanogen $^{3}$ ( $m c r A$ gene copies $/ 10^{9} \mu \mathrm{m}^{3}$ protozoal cell volume) & 0.661 & 0.062 & 0.092 & 0.115 & 0.045 & 0.321 & 93.874 \\
\hline
\end{tabular}

${ }^{1}$ Cell counts and average sizes of all protozoal species grouped within genera here as reported by Belanche et al. (2012).

${ }^{2}$ Reported cell counts multiplied by cell volume that was calculated using the currently proposed ellipsoid method using published width:depth values for listed genera from Williams and Coleman (1997). Data are total protozoal cell volume per filter fraction.

${ }^{3}$ Protozoal genomic DNA and methanogen methyl coenzyme M reductase $(\mathrm{mcr}) A$ gene copies taken from Belanche et al. (2014). 
Table 8. Simulated methane production per protozoal volume standardized for population type

\begin{tabular}{lccc}
\hline $\begin{array}{l}\text { Population } \\
\text { type }^{1}\end{array}$ & $\begin{array}{c}\text { Methane } \\
\left(\times 10^{5} \mu \mathrm{mol} / \mathrm{kg} \text { of DMI }\right)\end{array}$ & $\begin{array}{c}\text { Standardized single } \\
\text { cell volume } \\
\left(\times 10^{4} \mu \mathrm{m}^{3}\right)\end{array}$ & $\begin{array}{c}\text { Methane activity } \\
\left(\mu \mathrm{mol} \text { of } \mathrm{CH}_{4} / \mathrm{kg} \text { of DMI }\right) / \\
\left.\mu \mathrm{m}^{3} \text { of protozoa }\right]\end{array}$ \\
\hline $\mathrm{A}$ & 9.31 & 43.3 & 2.15 \\
$\mathrm{AB}$ & 9.69 & 27.1 & 3.58 \\
$\mathrm{~B}$ & 9.38 & 19.6 & 4.77 \\
$\mathrm{O}$ & 9.75 & 3.7 & 26.01 \\
\hline
\end{tabular}

${ }^{1}$ Population type (not described here) and methane production taken from Kittelmann et al. (2016).

${ }^{2}$ Proportion of protozoa in population type was multiplied by estimated cell volumes. Cell volumes were calculated using the ellipsoid method regression means (Figures 1, 2, 3) for Entodinium, Epidinium, and Isotricha; the ellipsoid formula was applied to average reported cell sizes for Eudiplodinium (Williams and Coleman, 1997), Diplodinium (Dehority, 2003), and Dasytricha (Belanche et al., 2012).

and family Ophryscolecidae within order Entodiniomorphida were shown to modify generation time according to genera or species (Karnati et al., 2009b; Sylvester et al., 2009; Ye, 2013), growth rate (Sylvester et al., 2009), and presumably ruminal passage rate (Diaz et al., 2014a). Therefore, the traditional concept of protozoa providing up to $50 \%$ of the rumen microbial biomass has been questioned and is probably unfeasible in lactating dairy cows (Firkins et al., 2007). About 15 to $20 \%$ of microbial $\mathrm{N}$ reaching the duodenum of dairy cattle should be protozoal N (Sok et al., 2017), but the protozoal contribution to microbial biomass (on an $\mathrm{N}$ basis) is still expected to be much less than $50 \%$ (Fessenden, 2016). Despite the importance of protozoal biomass - and therefore the amount of bacterial predation and $\mathrm{N}$ recycling - in microbial ecology and nutrition of ruminants, the literature has few studies that measured protozoal $\mathrm{N}$ pool size in the rumen simultaneously with ruminal outflow of protozoal N (Newbold et al., 2015). Because of the difficulty in fractionating protozoa from feed particles or bacteria, our current approach combined with improved values for biomass/volume can be used in future objectives that could dramatically shift expectations of contribution to protozoal $\mathrm{N}$ flow from the rumen, intraruminal recycling of microbial $\mathrm{N}$, and predictions of $\mathrm{N}$ supply to the ruminant.

\section{CONCLUSIONS}

In the present experiments, we tested a videographic method for objectively assessing protozoal motility responses to treatment using abrupt introductions of MON as a known toxic additive and CIN as a suspected inhibitory additive. Treatment with MON decreased measures of protozoal motility, whereas CIN decreased protozoal area and attenuated the effect of MON on protozoal speed (treatment interaction) at 3 $\mathrm{h}$ of incubation. These findings support an unexplained mechanism perhaps related to alteration of protozoal membrane by CIN. In a second experiment, regressions of residuals from proposed ellipsoidal volume estimates against a published coefficient method revealed that protozoal genera Entodinium and Epidinium were likely being overestimated for volume in literature estimates and that family Isotrichidae were likely being more accurately represented. In dairy cows, the latter are typically in low abundance, but the former (especially Entodinium spp.) are highly abundant. Therefore, accuracy in estimating protozoal volume changes with treatments in vivo or in vitro using actual dimensions used in the proposed new method should yield more consistent results when testing feed additives. More research and computer programming is needed to further automate the current videographic method for broader application in the field. However, the current approach greatly increases throughput compared with manual estimations for motility assessment, and our volume simulations from published studies support future objectives to include protozoal videography to improve our understanding of their role in the rumen.

\section{ACKNOWLEDGMENTS}

The authors are grateful to the late B. Dehority for his sharing a single culture of Epidinium caudatum and for his perspectives that shaped this research. We are also grateful to T. Hennessey for sharing the Tetratracker plugin for ImageJ. Research was jointly supported by state and federal funds appropriated to the Ohio Agricultural Research and Development Center, The Ohio State University. Funds were provided by the USDA National Institute of Food and Agriculture (Washington, DC) award 2012-67015-19437. This paper is manuscript number $02 / 18 \mathrm{AS}$ of The Ohio State University.

\section{REFERENCES}

Belanche, A., G. de la Fuente, J. M. Moorby, and C. J. Newbold. 2012. Bacterial protein degradation by different rumen protozoal groups. J. Anim. Sci. 90:4495-4504. 
Belanche, A., G. de la Fuente, and C. J. Newbold. 2014. Study of methanogen communities associated with different rumen protozoal populations. FEMS Microbiol. Ecol. 90:663-677.

Belanche, A., G. de la Fuente, and C. J. Newbold. 2015. Effect of progressive inoculation of fauna-free sheep with holotrich protozoa and total-fauna on rumen fermentation, microbial diversity and methane emissions. FEMS Microbiol. Ecol. 91:fiu026. https://doi .org $/ 10.1093 /$ femsec/fiu026.

Benchaar, C., and H. Greathead. 2011. Essential oils and opportunities to mitigate enteric methane emissions from ruminants. Anim. Feed Sci. Technol. 166:338-355.

Choi, J. W., and D. K. Stoecker. 1989. Effects of fixation on cell volume of marine planktonic protozoa. Appl. Environ. Microbiol. $55: 1761-1765$

Clarke, R. T. J., M. J. Ulyatt, and A. John. 1982. Variation in numbers and mass of ciliate protozoa in the rumens of sheep fed chaffed alfalfa (Medicago sativa). Appl. Environ. Microbiol. 43:1201-1204.

Czerkawski, J. W. 1984. Microbial fermentation in the rumen. Proc. Nutr. Soc. 43:101-118.

Dehority, B. A. 1984. Evaluation of subsampling and fixation procedures used for counting rumen protozoa. Appl. Environ. Microbiol. $48: 182-185$.

Dehority, B. A. 2003. Rumen Microbiology. Nottingham University Press, Nottingham, UK.

Dehority, B. A. 2006. Studies on the variation in caudal spination of Epidinium. Zootaxa 1305:33-39.

Dehority, B. A. 2010. Physiological characteristics of several rumen protozoa grown in vitro with observations on within and among species variation. Eur. J. Protistol. 46:271-279.

Dehority, B. A., and W. R. Mattos. 1978. Diurnal changes and effect of ration on concentrations of the rumen ciliate charon ventriculi. Appl. Environ. Microbiol. 36:953-958.

Dennis, S. M., M. J. Arambel, E. E. Bartley, and A. D. Dayton. 1983. Effect of energy concentration and source of nitrogen on numbers and types of rumen protozoa. J. Dairy Sci. 66:1248-1254.

Denton, B. L., L. E. Diese, J. L. Firkins, and T. J. Hackmann. 2015 Accumulation of reserve carbohydrate by rumen protozoa and bacteria in competition for glucose. Appl. Environ. Microbiol. $81: 1832-1838$.

Diaz, H. L., K. N. Barr, K. R. Godden, J. E. Plank, I. Zapata, A. N. Schappacher, W. P. Wick, and J. L. Firkins. 2014a. Eukaryotic inhibitors or activators elicit responses to chemosensory compounds by ruminal isotrichid and entodiniomorphid protozoa. J. Dairy Sci. 97:2254-2269

Diaz, H. L., S. K. R. Karnati, M. A. Lyons, B. A. Dehority, and J. L. Firkins. 2014b. Chemotaxis toward carbohydrates and peptides by mixed ruminal protozoa when fed, fasted, or incubated with polyunsaturated fatty acids. J. Dairy Sci. 97:2231-2243.

Eadie, J. M. 1962. Inter-relationships between certain rumen ciliate protozooa. J. Gen. Microbiol. 29:579-588.

Eadie, J. M., J. Hyhlgaard-Jensen, S. O. Mann, R. S. Reid, and F. G. Whitelaw. 1970. Observations on the microbiology and biochemistry of the rumen in cattle given different quantities of a pelleted barley ration. Br. J. Nutr. 24:157-177.

Eugène, M., H. Archimède, and D. Sauvant. 2004. Quantitative metaanalysis on the effects of defaunation of the rumen on growth, intake and digestion in ruminants. Livest. Prod. Sci. 85:81-97.

Fessenden, S. W. 2016. Amino acid supply in dairy cattle. in Animal Science. Ph.D. Dissertation. Cornell University, Ithaca, NY.

Firkins, J. L., Z. Yu, and M. Morrison. 2007. Ruminal nitrogen metabolism: Perspectives for integration of microbiology and nutrition for dairy. J. Dairy Sci. 90(E. Suppl.):E1-E16.

Hackstein, J. H. P., and A. G. M. Tielens. 2010. Hydrogenosomes, Pages 175-206 in (Endo)symbiotic Methanogenic Archaea. J. H. P. Hackstein, ed. Springer-Verlag, Heidelberg, Germany.

Harmeyer, J., and H. Hill. 1964. Das protozoenvolumen im panseninhalt bei zeige und guanako. Zbl. Vet. Med. 11:33.

Hennessey, T. M., and T. J. Lampert. 2012. Behavioral bioassays and their uses in Tetrahymena. Methods Cell Biol. 109:393-410.

Hristov, A. N., J. Oh, J. L. Firkins, J. Dijkstra, E. Kebreab, and G. Waghorn. 2013. Special topics-Mitigation of methane and nitrous oxide emissions from animal operations: I. A review of enteric methane mitigation options. J. Anim. Sci. 91:5045-5069.

Hungate, R. E., J. Reichl, and R. Prins. 1971. Parameters of rumen fermentation in a continuously fed sheep: Evidence of a microbial rumination pool. Appl. Microbiol. 22:1104-1113.

Ishaq, S. L., and A.-D. G. Wright. 2014. Design and validation of four new primers for next-generation sequencing to target the $18 \mathrm{~S}$ rRNA genes of gastrointestinal ciliate protozoa. Appl. Environ. Microbiol. 80:5515-5521.

Jouany, J. P. 1991. Rumen Microbial Metabolism and Ruminant Digestion. INRA Editions, Paris, France.

Jouany, J. P., and K. Ushida. 1999. The role of protozoa in feed digestion. Am. J. Appl. Sci. 12:113-128.

Karnati, S. K. R., J. T. Sylvester, S. M. Noftsger, Z. Yu, N. R. StPierre, and J. L. Firkins. 2007. Assessment of ruminal bacterial populations and protozoal generation time in cows fed different methionine sources. J. Dairy Sci. 90:798-809.

Karnati, S. K. R., J. T. Sylvester, C. V. D. M. Ribeiro, L. E. Gilligan, and J. L. Firkins. 2009a. Investigating unsaturated fat, monensin or bromoethanesulfonate in continuous cultures retaining ruminal protozoa. I. Fermentation, biohydrogenation, and microbial protein synthesis. J. Dairy Sci. 92:3849-3860.

Karnati, S. K. R., Z. Yu, and J. L. Firkins. 2009b. Investigating unsaturated fat, monensin, or bromoethanesulfonate in continuous cultures retaining ruminal protozoa. II. Interaction of treatment and presence of protozoa on prokaryotic communities. J. Dairy Sci. 92:3861-3873.

Kittelmann, S., S. R. Devente, M. R. Kirk, H. Seedorf, B. A. Dehority, and P. H. Janssen. 2015. Phylogeny of the intestinal ciliates including first sequences from Charonina ventriculi and comparison of microscopy and 18S rRNA gene pyrosequencing for rumen ciliate community structure analysis. Appl. Environ. Microbiol. 81:2433-2444.

Kittelmann, S., C. S. Pinares-Patino, H. Seedorf, M. R. Kirk, J. C. McEwan, and P. H. Janssen. 2016. Natural variation in methane emission of sheep fed on a lucerne pellet diet is unrelated to rumen ciliate community type. Microbiology 162:459-465.

Krumholz, L. R., C. W. Forsberg, and D. M. Veira. 1983. Association of methanogenic bacteria with rumen protozoa. Can. J. Microbiol. 29:676-680

Leick, V., C. Iversen, K. Kemp, and S. T. Christensen. 1997. Protein kinase inhibitors abolish adaptive cell behavior in Tetrahymena Acta Protozool. 36:249-260.

McGuffey, R. K., L. F. Richardson, and J. I. D. Wilkinson. 2001. Ionophores for dairy cattle: Current status and future outlook. J. Dairy Sci. 84(E. Suppl.):E194-E203.

Nam, S.-W., S.-T. Kim, K.-M. Lee, S. H. Kim, S. Kou, J. Lim, H. Hwang, M. K. Joo, B. Jeong, S. H. Yoo, and S. Park. 2009. N Methyl-D-aspartate receptor-mediated chemotaxis and $\mathrm{Ca}^{2+}$ signaling in Tetrahymena pyriformis. Protist 160:331-342.

Newbold, C. J., G. de la Fuente, A. Belanche, E. Ramos-Morales, and N. R. McEwan. 2015. The role of ciliate protozoa in the rumen. Front. Microbiol. 6:1313.

Reveneau, C. S. K. R. Karnati, E. R. Oelker, and J. L. Firkins. 2012 Interaction of unsaturated fat or coconut oil with monensin in lactating dairy cows fed twelve times daily. I. Protozoal abundance, nutrient digestibility, and microbial protein flow to the omasum. J. Dairy Sci. 95:2046-2060.

Russell, J. B. 2002. Rumen microbiology and its role in ruminant nutrition. Cornell University, Ithaca, NY.

Schneider, C. A., W. S. Rasband, and K. W. Eliceiri. 2012. NIH Image to ImageJ: 25 years of image analysis. Nat. Methods 9:671-675.

Sieracki, M. E., C. L. Viles, and K. L. Webb. 1989. Algorithm to estimate cell biovolume using image analyzed microscopy. Cytometry 10:551-557.

Sok, M., D. R. Ouellet, J. L. Firkins, D. Pellerin, and H. Lapierre. 2017. Amino acid composition of rumen bacteria and protozoa in cattle. J. Dairy Sci. 100:5241-5249.

St-Pierre, N. R. 2003. Reassessment of biases in predicted nitrogen flows to the duodenum by NRC 2001. J. Dairy Sci. 86:344-350. 
Sylvester, J. T., S. K. R. Karnati, B. A. Dehority, M. Morrison, G. L. Smith, N. R. St-Pierre, and J. L. Firkins. 2009. Rumen protozoa decrease generation time and adjust $18 \mathrm{~S}$ ribosomal DNA copies to adapt to decreased transfer interval, starvation, and monensin. J. Dairy Sci. 92:256-269.

Sylvester, J. T., S. K. R. Karnati, Z. Yu, M. Morrison, and J. L. Firkins. 2004. Development of an assay to quantify rumen ciliate protozoal biomass in cows using real-time pcr. J. Nutr. 134:3378-3384.

Sylvester, J. T., S. K. R. Karnati, Z. Yu, C. J. Newbold, and J. L. Firkins. 2005. Evaluation of a real-time pcr assay for measuring the ruminal pool and duodenal flow of protozoal nitrogen. J. Dairy Sci. 88:2083-2095.

Teather, R. M., S. Mahadevan, J. D. Erfle, and F. D. Sauer. 1984 Negative correlation between protozoal and bacterial levels in rumen samples and its relation to the determination of dietary effects on the rumen microbial population. Appl. Environ. Microbiol. 47:566-570.

Towne, G., and T. G. Nagaraja. 1990. Omasal ciliated protozoa in cattle, bison, and sheep. Appl. Environ. Microbiol. 56:409-412.

Towne, G., T. G. Nagaraja, R. T. Brandt Jr., and K. E. Kemp. 1990. Dynamics of ruminal ciliated protozoa in feedlot cattle. Appl. Environ. Microbiol. 56:3174-3178.

Vogels, G. D., W. F. Hoppe, and C. K. Stumm. 1980. Associations of methanogenic bacteria with rumen ciliates. Appl. Environ. Microbiol. 40:608-612.
Weller, R. A., and A. F. Pilgrim. 1974. Passage of protozoa and volatile fatty acids from the rumen of the sheep and from a continuous in vitro fermentation system. Br. J. Nutr. 32:341-351.

Wenner, B. A. 2016. Effects of aqueous hydrogen on methane mitigation in continuous culture fermenters. PhD Diss. The Ohio State University, Columbus.

Whitelaw, F. G., J. M. Eadie, L. A. Bruce, and W. J. Shand. 1984 Methane formation in faunated and ciliate-free cattle and its relationship with rumen volatile fatty acid proportions. Br. J. Nutr. 52:261-275.

Williams, A. G. and G. S. Coleman. 1992. The Rumen Protozoa. Springer-Verlag, New York, NY.

Williams, A. G., and G. S. Coleman. 1997. The rumen protozoa. Pages 73-139 in The Rumen Microbial Ecosystem. 2nd ed. P. N. Hobson and C. S. Stewart, ed. Blackie Academic \& Professional, New York, NY.

Ye, D. 2013. Examining the effects of adding fat, ionophores, essential oils, and Megasphaera elsdinii on ruminal fermentation with methods in vitro and in vivo. $\mathrm{PhD}$ Thesis. The Ohio State University, Columbus. 